\section{Assessing the role of Brazil in the New World Order: a geopolitical study of Meridionalism and neo-Eurasianism ${ }^{1}$}

\author{
Evaluando el papel de Brasil en el nuevo orden mundial: \\ un estudio geopolítico del meridionalismo \\ y neo-eurasianismo
}

\author{
Nuno Morgado ${ }^{2}$ \\ INSTITUTE OF POLITICAL STUDIES \\ CHARLES UNIVERSITY IN PRAGUE \\ CZECH REPUBLIC \\ $\triangle$ morgado@fsv.cuni.cz
}

Anuario Latinoamericano Ciencias Políticas

y Relaciones Internacionales vol. 4, 2017

pp. $163-186$

DOI: $10.17951 /$ al.2017.4.163

\begin{abstract}
This article offers a perspective on the study of the connections between neoEurasianism and Meridionalism. Its main argument is that there exists a possible tendency of Meridionalism becoming an instrument of neo-Eurasianism - and by extension of Russian national interests - in Latin America. Although Russian interference in Brazil is not new, the bonds between Meridionalism and neoEurasianism may now assume a clearer than ever aspect in strategic terms between the two countries. It is also noteworthy that both those formulations came from academia.

There is a particular logical inconsistency to be pointed out within Meridionalism: either an ideological purpose overcomes geostrategic goals or the opposite. In order to solve that problem, the article is structured in two parts: a short look at the Brazilian School of Geopolitics' cores and the comparative analysis of Meridionalism and neoEurasianism.

The theoretical and methodological framework is linked to the realist theoretical

1 This article is an output of the research project no. 260 230/2015 "Changes and Consequences of Political Institutions" from the Institute of Political Studies (SVV), Faculty of Social Sciences, Charles University in Prague. A.M.D.G. Earlier version of this paper was presented at the IPSA 24 ${ }^{\text {th }}$ World Congress of Political Science in Poznań, Poland.

$2 \mathrm{PhD}$ Candidate in International Relations. Area of specialization: Geopolitical Studies. Master degree with honors in Strategic Studies, Institute of Political and Social Sciences, University of Lisbon. Bachelor degree with honors in Political Science and International Relations, Faculty of Social Sciences and Humanities, New University of Lisbon.
\end{abstract}


tradition (positivism), with a mixture of geopolitical studies approach and strategic planning framework. Geopolitical studies simply provide the tools to explain the Brazilian School of Geopolitics' ideas and to identify geopolitical factors within the strategic plans. Together with strategic planning, the comparative analysis of Meridionalism and neo-Eurasianism, as strategic plans, is accomplished.

KEYWORDS: geopolitical studies, Meridionalism, neo-Eurasianism, realism, foreign policy.

\section{RESUMEN}

Este artículo ofrece una perspectiva sobre el estudio de las conexiones entre el neo-eurasianismo y el meridionalismo. Su argumento principal se basa sobre una posible tendencia de que el meridionalismo se convierta en un instrumento del neo-eurasianismo - y por extensión de los intereses nacionales rusos - en América Latina. Aunque la interferencia rusa en Brasil no es nueva, los vínculos entre meridionalismo y neo-eurasianismo pueden ahora asumir un aspecto más claro en términos estratégicos entre los dos países como nunca antes. También cabe destacar que ambas formulaciones provienen de la academia.

Hay una incoherencia lógica particular que debe señalarse en el meridionalismo: o bien el objetivo ideológico supera los objetivos geoestratégicos o bien lo contrario. Para resolver este problema, la estructura del artículo se compone de dos partes: una breve mirada a los núcleos de la Escuela Brasileña de Geopolítica y el análisis comparativo del meridionalismo y neo-eurasianismo.

El marco teórico y metodológico está vinculado a la tradición teórica realista (positivismo), con una mezcla de enfoques de estudios geopoliticos y de la estructura de planificación estratégica. Los estudios geopolíticos facilitan las herramientas para explicar las ideas de la Escuela Brasileña de Geopolítica e identificar los factores geopolíticos dentro de los planes estratégicos. Junto con la planificación estratégica, se realiza el análisis comparativo del meridionalismo y neo-eurasianismo, como planes estratégicos.

PALABRAS CLAVE: estudios geopolíticos, meridionalismo, neo-eurasianismo, realismo, política exterior.

\section{INTRODUCTION}

The main objective of this article is to identify links between neo-Eurasianism as Russian strategic plan and Meridionalism as Brazilian strategic plan. The article argues that the hypothesis of Meridionalism being used by neoEurasianism in a global modality of action is confirmed and it is sustained that such scenario will continue in the future if major changes do not occur.

The article's structure is divided into two parts: a very brief description of the Brazilian School of Geopolitics' cores in order to identify the prescrip- 
tion of "continentalization directive" as predominant idea, which will be later found in Meridionalism; and a more thoughtful analysis of neo-Eurasianism and Meridionalism demonstrating converging positions and objectives, and making the argument of the subordination of the latter to the previous one.

As for the theoretical perspective, the article is positioned in the positivist sphere and inscribed in the realist theoretical tradition, putting forward a mixed approach of geopolitical studies with strategic studies. Particularly in respect to the latter, the discipline of strategic planning offers suitable instruments that were used extensively. The sources of the research were mainly books, papers, chapters and conferences/oral communications by main authors of the Brazilian School of Geopolitics, neo-Eurasianism and Meridionalism.

\section{Cores in the Brazilian School of Geopolitics}

Mário Travassos' work - the first one formulating a study in the geopolitical sphere in Brazil - can be systematized in three general postulates, which are still useful today in geopolitical analysis: a) states tend to control the entire area of a river basin as well as the mouth of the river; b) states aim to have several accesses to the sea and when it is possible to different seas; c) states tend to dominate "routes" that eventually can be used for state's power projection. Travassos focused on infrastructures, communication lines, strategic planning and centralization.

Departing from that series of ideas, the Brazilian School of Geopolitics concentrated on: territorial integration and defense of national territory, diplomatic cooperation with other South-American countries (especially from the southern cone), and prestige enlargement in continental terms.

Mattos, the classic author, summarized the Brazilian School of Geopolitics in the following points (Meira Mattos 2011: 208): a) the idea of empire while considering the dimension of the territory; b) the necessity of territorial colonization/integration (state's relative potential); c) development and defense of the Amazon region; ${ }^{3}$ d) strategic position of Brazil in the South Atlantic; e) aeronautic development is essential to Brazil's territorial integration; $f$ ) economic, social, scientific and technological development policies are imperative; g) Brazil has sufficient conditions to become a great power; h) in order to dissuade international ambitions, Brazil needs strong armed forces; i) competent diplomacy is vital to pursue national aspirations and objectives.

Hence, those points could be systematized into the following objectives: protection of the North, Brazilian presence in Antarctica, the idea of South Atlantic Pact (Miyamoto 1987: 7). The danger of an attack, foreign penetration in the Amazon area is recurrent too (Meira Mattos 2011: 220).

3 It is noteworthy the existence of a very recent study on this topic by the Secretaria de Assuntos Estratégicos da Presidência da República (Gheller et al. 2015).
Assessing the role of Brazil in the New World Order: A geopolitical study of Meridionalism and neo-Eurasianism

Nuno Morgado 
Therefore, the mainstream of the Brazilian School of Geopolitics was the continentalization strategy (Travassos and Meira Mattos predominantly) (see: Morgado 2016). Apt to be characterized as "classical geopolitics", the Brazilian School of Geopolitics formulated recommendations to the political power, of which the most recurrent one was to focus on the continentalization dynamics. Meridionalism continued de facto such state-of-things, although there are inconsistencies to be pointed out.

\section{Comparative analysis of Meridionalism and neo-Eurasianism}

Although the order of words in the title and subtitle presented Meridionalism in the first place - since the article is devoted to the role of the position of Brazil concerning two strategic plans - due to the following facts: neo-Eurasianism anticipated Meridionalism in the line of time, and neo-Eurasianism is richer in theoretical terms (thus, neo-Eurasianism helps understand Meridionalism), neo-Eurasianism will be analyzed first and Meridionalism afterwards.

\section{Fundamental lines of neo-Eurasianism as strategic plan}

After explaining the cores of the Brazilian School of Geopolitics, this section shall start by stating that neo-Eurasianism is not only a strategic plan but also an ideology, since, for example, it misuses geopolitical concepts in favor of the primary goal of achieving power.

Yet, leaving ideology aside, the next research step shall focus on what neo-Eurasianism presents as "ideal" New World Order and how neo-Eurasianism intends to implement the changes to reach that "final stage", i.e. which tactics have been designed by its major proponent, the Russian author Aleksandr Dugin.

Map 1.

The West as target by Dugin (2000: 217)

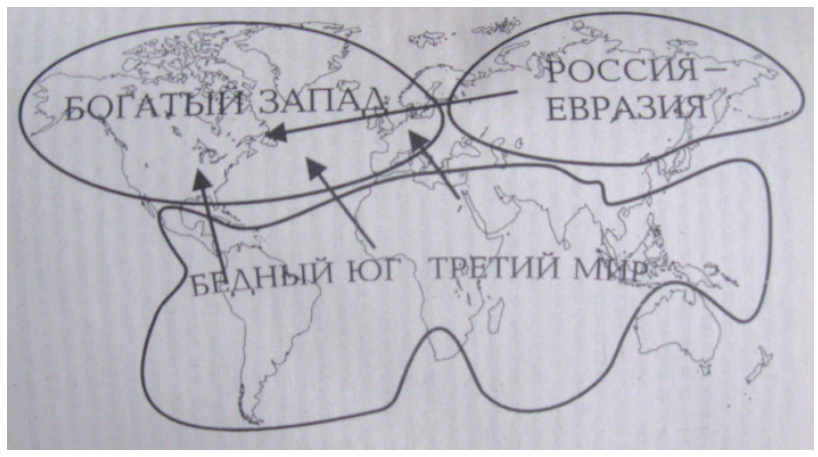


Right from the beginning of this section, it will be demonstrated that the very first modality of action of neo-Eurasianism, as a strategic plan, is to gather as much support as possible against the West and, most of all, against the U.S.A.

With both neo-Eurasianism and Meridionalism perceived as strategic plans, the study will, therefore, be able to decompose two phases within them, with the assistance of strategic planning framework.

The first phase of strategic planning ${ }^{4}$ requires the analysis of the environment: an internal analysis (identifying strengths and weaknesses) and an external analysis (naming the opportunities and threats, i.e. SWOT analysis). The second phase is composed of the formulation of the plan, which includes: the definition of the mission, the enumeration of objectives, setting up modalities of action and linking the plan to specific sectoral policies. These two phases are covered by neo-Eurasianist and Meridionalist strategic plans, as the study will verify in detail. ${ }^{5}$

\section{Phase I. Analysis of the international environment by neo-Eurasianism}

The geopolitical approach concerns the international environment primarily, but not exclusively. However, due to space limitations of this article, the analysis of the internal environment will be left aside.

In general - and focused mainly on the international arena anyway - Dugin has begun his books, articles, interviews, conferences, broadcasts devoted to explaining his - that is neo-Eurasianist - Weltanschauung with the image that the U.S.A., "the American Empire", is collapsing and that the "unipolar world" will soon cease to exist. This "American Empire" or "unipolarism", Dugin explained, comprises several dimensions. The World Order is unipolar and the U.S.A. is the core of the unipolarity. This unipolarity is: a) geopolitical - dominance of the globe by the U.S. imperialism that established a kind of "global dictatorship"; b) ideological - "...based on the Modernist and PostModernist values..."; c) spiritual - it is the "...kingdom of the Antichrist" (Dugin 2011). Consequently, Dugin labeled a “...USA-centric global geopolitical field..." that assumes impact in several domains: historically - the U.S. conception of Western Civilization's climax; politically and ideologically - the spread of liberal democracy throughout the world; economically - the U.S.A. expands its economy worldwide, uses military invasions to assist in that process, and that expansion is only limited by the Chinese economic strength and the monopoly of resources by Russia, Iran and Venezuela (Dugin 2011). In another source, Dugin criticized the Western anthropological individualism,

\footnotetext{
4 Elsewhere the author explained with detail strategic planning's phases, also providing an application of that model on the empirical reality (Morgado 2015).

5 The other two phases of strategic planning: operationalization, and evaluation and control - as future events as a whole - shall be for that reason put aside.
}

Assessing the role of Brazil in the New World Order: A geopolitical study of Meridionalism and neo-Eurasianism

Nuno Morgado 
belief in progress, technological development, Euro-American centrism, free market economy, democracy as the rule of minorities [sic], the middle class as the only really existing social actor and universal norm, one-world globalism (world citizenship) (Dugin 2014a: 295).

So all these claims have been organized into a compact bloc of ideas in order to denounce that the U.S.A. are pursuing “... the promotion of 'universal' values reflecting the values of Western world (liberal democracy, parliamentarism, free market, human rights and so on)" (Dugin 2011). Upper bourgeois class is the dominant class in a financial and industrial imperialism, imposing "...a kind of 'global imperial network' operating on a planetary scale" (Dugin 2011) and that - this is a vital point - the U.S. move towards "world domination" accomplishing it at Russian expense (Dugin 2014a: 125).

Therefore, one has now Dugin's picture of the World Order and one can summarize: the West rules under the U.S. command, and rules over a multitude of states - including Russia - that can barely resist to this supremacy. The situation is then unfair and should change as soon as possible, Dugin concluded.

With the purpose of covering this approach with more respectable justification, a misuse of the geopolitical approach was brought. ${ }^{6}$ In the pure Manichean division, Russia and its allies are identified with reactionary telluropolitics, and the U.S.A. and its allies, including NATO, are identified with imperialistic thalassopolitics. Nevertheless, the highest respectability comes with duginist moral standards: the West is the "evil" and Eurasia is the "good".

Using process tracing, it is possible to infer that Dugin's analysis of the external environment and his "refusal of the West"7 is mainly based on the criticism of a single book: The Open Society and Its Enemies by Karl Popper (Dugin 2006: 131-134). Ignoring the fact that judging a whole civilization by one book only is nothing but a dishonest approach, a non-scientific one, Dugin's misguided approach is moreover revealed while recognizing an allegedly "American imperialism" (free world, crusade for democracy, Atlantic solidarity), paying no attention to the opposing values that, being also part of the West, react against Dugin's picture, e.g. aspects of classic Greek philosophy, some Roman law principles, Christianity itself, so many political thinkers (e.g. de Maistre, Fortunato, Cortes, Kirk), generals, philosophers; values expressed in all cultural dimensions, from architecture to music, painting, etc.).

One of the biggest problems in Dugin's approach lies in his definition of globalization. Dugin has been confusing definitions. He does not use an

6 Namely misusing concepts such as: (1) Heartland; (2) Thalassopolitics and Telluropolitics, i.e. a "clash Sea vs Land" (3) Pan-Regions and Civilizations.

7 "I am resolutely against the Western values..." - Alexandr Dugin (2011). 
academic definition of unipolar world ${ }^{8}$, but instead he has been using the "unipolar world" expression as unilateralism, in the sense that "the U.S. does everything it wants". Hence, the intentions in this attitude cannot be other than ideological.

\section{Phase II. Formulation of strategic plan by neo-Eurasianism}

The formulation of the mission guarantees the unity of the whole strategic plan. National survival, territorial integrity and people's welfare put together the mission of the regular and efficient state's structure.

As for the official mission of neo-Eurasianism, its supreme command can be recognized in the destruction of the "unipolar world". Hypothetically, this mission should be accomplished through the creation of multipolarity - i.e. Russia is unable to create a unipolar order, not even able to sustain the old bipolar order, multipolarity is the only possible comfortable and affordable solution.

Having already presented Dugin's despise for the "Roman-German civilization" and its "universalism" (Dugin 2014b: 18), Western hegemony must then be exterminated. Dugin presented his theses interrelated with the mission though (Dugin 2006: 55-59): a) the West needs to be saved; b) Russia is a specific civilization that not only needs to be saved too, but also developed (against Americanization); c) strengthening of a Russian strategy, e.g. improving Russian economy.

At this level appears the following doubt: is the destruction of the "unipolar world" the true neo-Eurasianist mission only, or does that mission embrace the destruction of the U.S.A. as a country too? KGB-trained scholar Panarin, also a proponent of a continental Eurasian bloc, formulated the hypothesis of U.S. dismantle, a prediction that was not confirmed by Panarin's own deadline of 2010 (Scalea 2009). Yet, the project (or aspiration) has not been vanished or repudiated.

How is the mission divided? Certainly into a list of objectives: the official creation of "multipolarity" or great spaces on the international chessboard (assessed as fake); being inferred the true objective on establishing Russia as major great power with a very strong supremacy over the old Soviet space, adding series of strong alliances with several countries - an oligarchic global order.

The systematization of objective follows the pattern of the official neoEurasianist analysis of the environment, i.e. the foundations of project lays in the rejection of Atlantism, NATO, and the US-led globalization. The main point is allegedly raising a multipolar world of "four great spaces" headed by four director-states: Russia, Germany, Japan, and the U.S.A. Naturally, Russia

8 For example: "a distribution of measurable capabilities among states such that there is only one super power", one state only is "above the rest in terms of basic capabilities" - those are William C. Wohlforth's statements (Johns Hopkins 2015) (Wohlforth 1999: 7).
Assessing the role of Brazil in the New World Order: A geopolitical study of Meridionalism and neo-Eurasianism

Nuno Morgado 
Artículos y ensayos

Map 2.

Dugin's Eurasian Empire

(Dugin 2000: 415) would have a role of hegemonic power and would hold concrete plans towards some countries (e.g. secession of Turkey, Azerbaijan or China and absorption of Finland by Russia).

Whereas the mission and the objectives constitute what is to be achieved, the modalities of action compose the directives on how to accomplish it.

It was already pointed out that gathering the greatest number of U.S. enemies and opponents is the neo-Eurasianist main modality of action. Based on Leninist-Gramscian teachings, Dugin (2011) explained that:

- "...[he] is radically against American hegemony and world domination [...] against globalism and proposes the doctrine of multipolarity. [He is] in favor of the common struggle of Russians, Muslims, Asians and Latins against the countries of Rich North".

- "Movements against the U.S. world-leadership: (1) Global Caliphate and the radical Islam; (2) neo-socialism movement (e.g. Venezuela, Bolivia, [Brazil]); Eurasian project, i.e. multipolarity... based on the principle of civilizations and great spaces".

- "...who challenge the present state of things, the globalization and the American imperialism are virtually friends and allies. Let our ideals be different but we have in common one very strong thing: the present reality that we hate".

Hence, one has a great heterogeneity among numerous allies. The expressions “Third Rome, Third Reich, Third International" (Dugin 2016a) may give a more precise idea about the incompatibility among the allies that are brought together solely on the grounds of common hostility towards the U.S.A. and the West.

Dugin has been presenting modalities of action based on sophisticated techniques of subversion, destabilization and disinformation, masterminded by the Russian intelligence community. In this sense, Dugin affirmed that only the army and the secret services possess a real sense of patriotism (Dugin 2008), something that Dugin certainly knows very well, taking into account his family origins linked to arcana imperii for generations, i.e. to GRU/KGB.

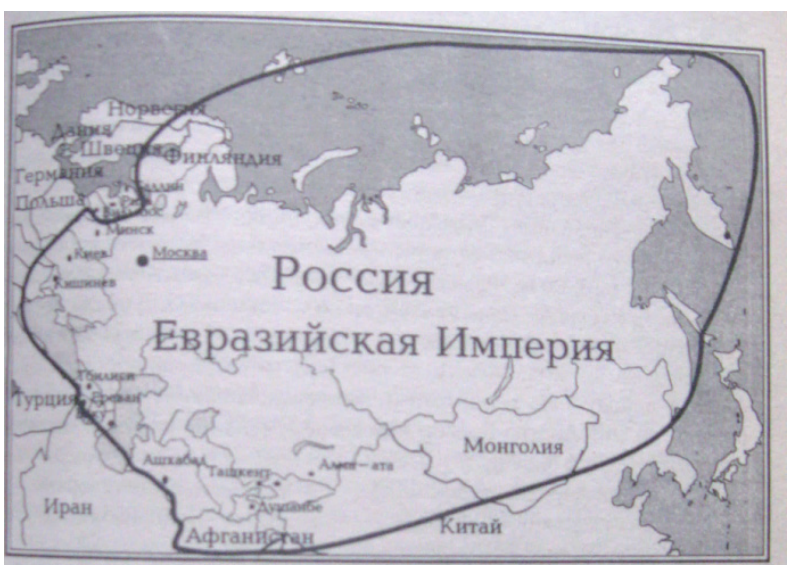


However, concerning the Armed Forces, in the neo-Eurasianist modalities of action military operations play relatively little role, while the use of resources (i.e. a geopolitical factor), for example, natural gas or oil, is seen as a vital weapon for pressuring other states. In this regard, the modality of action should in extremis achieve the point of making all of Europe captive of Russian resources.

In this context, an aggressive and radical foreign policy conducted mainly by secret services is the issue at stake in a manner of: working for Eurasian integration; and encouraging the foundation of "great spaces" and alliances between them and Russia.

Working for Eurasian integration is based, before anything else, on Russia's position in the middle of Eurasian mass land. ${ }^{9}$ Russia should make the unification of all "Russian territory" and find its true dimension, Dugin assumed. In fact, the Empire is one of the goals for neo-Eurasianism. ${ }^{10}$

The foundation of "great spaces" and bilateral alliances between them and Russia is another modality of action for neo-Eurasianism. Against the logics that different peoples have different national interests, Dugin projected the construction of four "great spaces" (as once four Haushofer's pan-regions): a) the American Continent (Monroe doctrine led by the U.S.A.); b) EuroAfrica, headed by "Central Europe"; c) Russian Central-Asian zone, headed by Russia; and d) the Pacific zone, headed by Japan (Dugin 2014b: 47-49).

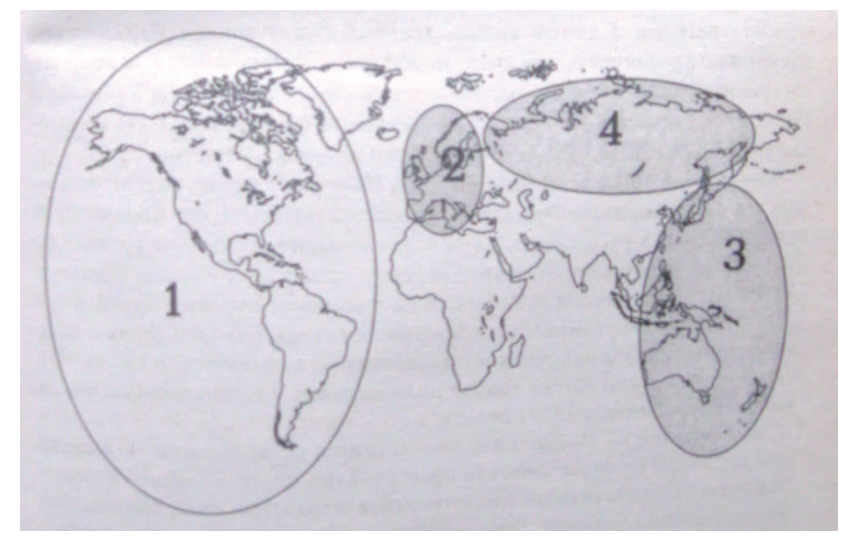

9 For a reading about Russia's position from the geopolitical point of view see: Michael Romancov (2006).

10 "An Empire in Place of a National State" - Dugin (2014a: 63-67).
Assessing the role of Brazil in the New World Order:

A geopolitical study of Meridionalism and neo-Eurasianism

Nuno Morgado

Map 3.

Dugin's multipolar World Order (four zones) (Dugin 2000: 235) 
Artículos y ensayos

Map 4.

Dugin's 'Multipolar World: Four Zones - Large Spaces'

(Dugin 2014b: 58)
To those four great spaces, Dugin added series of blocs: the European Union, Eurasian Union, Islamic Union, the South-American Union ${ }^{11}$, Chinese Union, the Indian Union, Pan-Pacific Union, the North-American great space (Dugin 2011), in which economic, military and political partnership should prevail (Dugin 2014b: 49).

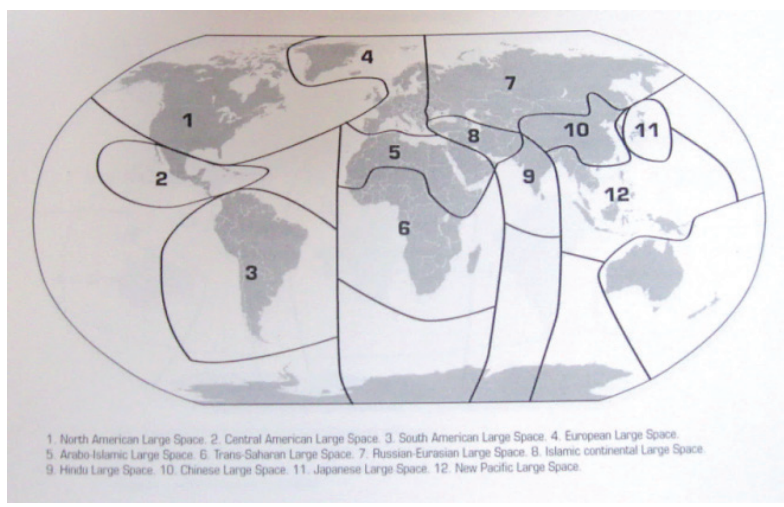

Besides that, another core of the modality of action under study is comprised by the idea of axes. Dugin presented three of them: the Moscow Berlin Axis (Dugin 2000: 220-229), the Moscow - Tokyo Axis (Dugin 2000: 229-238), and the Moscow - Teheran Axis (Dugin 2000: 238-246).

Eurasian "...temporary allies (Islamists, Latin America anti-colonialists, neo-socialists and 'independistas' and so on)" (Dugin 2011) also have their place. Dugin admitted to neutralize those alliances later on - in the line of Leninist-Gramscian dialectic.

In the Third World, Russia should stimulate integration projects among the countries under great powers allied with Russia, Dugin clarified (Dugin 2006: 28). At this point, Brazil, São Paulo Forum and Latin America regional integration enters the topic.

So, what about Brazil? What about its relevance in the Neo-Eurasianist strategic plan?

Before the debate between Dugin and Brazilian philosopher Olavo de Carvalho, which took place in 2011, one cannot find major references from Dugin - or from the neo-Eurasianist movement in general - to Brazil, or even to Latin America. Therefore, it might be argued that the incorporation of the region in the neo-Eurasianist strategic plan has been recent.

Nevertheless, Russia's - and before Russia the Soviet bloc's - interest in Brazil dates back in time, and this constitutes a topic that has not been

${ }^{11}$ This study understands that São Paulo Forum and South America regional integration represent that political process. 
properly analyzed by the literature in political science either. Several former intelligence agents from the Soviet bloc exposed USSR's influence in Brazil. Pacepa, a former Securitate (Romanian communist secret police) three-star general, confessed that liberation theology was originated directly from Khrushchev's goal of attaining influence over Latin America. This means that for reaching that goal, the KGB elaborated and used liberation theology to pursue communist infiltration in Brazil's Catholic Church, destroying true Catholic doctrine in this way (Pacepa 2015).

Former StB operative (Státní bezpečnosti - Czechoslovak communist secret police) Ladislav Bittman ${ }^{12}$ - who, like Pacepa, defected to the U.S.A. admitted in his book that in February 1964, StB was responsible for creating fake documents released in Brazilian mass media, stating that the U.S.A. was preparing an intervention in Brazil and that many CIA, FBI, DOD agents were already deployed in the country (Bittman 1985) - an example of pure disinformation.

Mauro Abranches has been studying documentation at The Institute for the Study of Totalitarian Regimes in Prague and disclosed that StB TORO operation, launched in Brazil against the U.S. ambassador Thomas Clifton Mann (1912-1999), fabricated facts and forged documents, spreading them in Brazilian mass media. Abranches proved from the documents that roughly 31 operations were launched in Brazil by StB/KGB (Magalhães 2014a) ${ }^{13}$, confirming Bittman's explanations. Nevertheless, until now and against all empirical data, the narrative that 1964 political disturbance in Brazil was caused by the U.S.A. remains solid in leftist Brazilian mass media and academia.

Furthermore, in the documentary "Soviet Subversion of the Free World Press", former KGB agent Yuri Bezmenov (Freeman 2014) - who, like Pacepa and Bittman, also defected to North America (in his case to Canada) explained in detail the techniques for ideological brainwashing used on foreign diplomats, journalists, poets, intellectuals and editors resident or visiting Moscow, ${ }^{14}$ providing even stronger support to the previous descriptions. From this short review, one infers that USSR/Russia was and still is perfectly aware of Brazil's potential as a target.

Coming back to the present and to neo-Eurasianism, one can observe the continuation of the pattern of Russia's interest in Brazil. In the mentioned debate with Carvalho, Dugin even compared Brazil with Russia as culture-mixed

12 Ladislav Bittman was the same agent who was involved in the 1964 disinformation operation (Operation Neptune), forging fake Nazi documentation, planting that documentation on the bottom of Black and Devil's Lakes in southern Czechoslovakia, and then recovering it publicly in order to harm the image of the West, particularly Federal Republic of Germany, fomenting anti-Nazi hysteria and creating internal problems in the free world. This operation even made some people - whose names were mentioned in the fake documents - commit suicide. Bittman confessed these crimes in an interview (Fdfrankify 2012).

${ }^{13}$ For other StB operations in Brazil see: Magalhães (2014b) and Abranches and Petrilák (2016).

14 For example, among many others, a Brazilian journalist recruited by the KGB: ABI (2009).
Assessing the role of Brazil in the New World Order: A geopolitical study of Meridionalism and neo-Eurasianism

Nuno Morgado 
countries with particular identity, "metaphorically both are Eurasian countries". The objective is then revealed - stimuli for increasing the degradation of relations between Brazil and the U.S.A., which Dugin called “independence" (Dugin 2011).

From this premise, the question arises: if Brazil has a specific identity as Dugin (correctly) said, then how can Brazil be merged in a Latin American Großraum without damaging this identity, which neo-Eurasianism states it is aiming to protect? The answer is obvious: the priority is not Brazil's identity, but the construction of a Latin America "greater space" that can become an instrument of the neo-Eurasianist strategic plan. The text will insist in this argument.

Dugin prepared a mental terrain for planting his seeds:

As far as I understand, Brazilian society and Brazilian culture are not fully Western and individualistic. [...] the main features of Brazilian cultural [critical] attitude towards USA. [...] Being critical in front of USA and the Western civilization as a whole, I find a lot of very charming [Eurasian] features in the South and Central American societies. [...] It seems that Latin America is more and more inclined to choose the alternative approaching the Eurasian and Arab camps (Dugin 2011).

Neo-Eurasianist think tank Katehon declared that Brazil's "geopolitical balance is $70 \%$ Eurasianist and 30\% Atlanticist" (Katehon 2016). Although there is no information about which methodology was used to get this result, all the quotes and the mentioned empirical data converge to the cited modality of action: the unification of Latin America into a single bloc.

If doubts resist, one shall confirm directly in another Dugin's writing: Dugin advised directly for "the integration of Latin American countries into Central and South American Great Spaces" (Dugin 2014: 75, Laos 2015: 160) and identified Latin America in general as a Großraum, a Greater Space (Dugin 2016b). Naturally, this is a mistake, since Brazil, contrary to the rest of Latin American countries, is a Portuguese-speaking country, thus with a different culture. But to Dugin that is a non-important detail in the whole strategic plan. Moreover, on the one hand, Dugin promised Latin America to the U.S. control (Monroe doctrine) whereas, on the other hand, Dugin asserts that Brazilians should fight against the U.S.A. This confusion corresponds to the contradictions of revolutionary dialectics.

Bringing Parvulesco - a late friend and collaborator of Dugin's - to the analysis, he also formulated plans concerning the region under study. Latin America - Parvulesco called it, not incorrectly, "Roman America" - can be a gateway for the Eurasian project against the U.S.A., in the same way that China - Parvulesco said - is a gateway within the "Great Eurasian continent" in favor of the U.S.A. (Parvulesco 2005: 285). In this way, the use (in the LeninistGramscian sense) of South America by the Eurasian project is highly favored by the Latin America integration - Parvulesco admitted it openly, revealing the unity in the neo-Eurasianist modalities of action (Parvulesco 2005: 286-288). 
If, in terms of political reality, Brazil has been buying military equipment from Russia - like aerospace defense equipment (Lulko 2013) - under an agreement signed in 2008 (in Lula da Silva's time in office), further political connections (BRICS, special talks, etc.) cannot be surprising either. "So, the national States lack the vision, and movements lack sufficient infrastructure to put their ideas in practice"- Dugin prescribed (2011).

In Latin America, the regional integration process, which enchants neoEurasianism so much, has a directive strategic body: the São Paulo Forum. Unfortunately this topic must be postponed for another research, due to its complexity. Yet it had to be mentioned due to its relevance in the power network.

In conclusion, Brazil has not been ignored by neo-Eurasianism. On the contrary, since at least 2011, Dugin has been elaborating on the importance of Brazil and Latin America for his strategic plan. The role of Meridionalism and the conduct of politics in South America are both instruments that neoEurasianism can use, in order to achieve its mission.

The Phase II is ended by 4 sectoral politics. Much could be explained at this level, but for the sake of shortness of the text, only two aspects shall be highlighted, for their direct connection to the geopolitical factors.

Firstly, neo-Eurasianism, in the quality of a totalitarian ideology, provides a program for all human dimensions: from housing to health, passing by culture, religion, finance and, of course, politics and economy.

Secondly, the subject of police/secret service-state, the agent par excellence of neo-Eurasianism. If doubts about the totalitarian and police-oppressivestate character of neo-Eurasianism persist, Dugin's idea that the new Eurasian elite need to rotate from "parallel hierarchies" to an "Oprichnina" - that means to praise the formation of another secret service or a secret police body - may be borne in mind (Dugin 2014: 183-187).

Therefore, Dugin captured geopolitical concepts and theories, imposed them as a necessity and created a strategic plan for achieving objectives. The enemy was identified - the U.S.A. and the West - and then the destruction of their hegemony in the world was crystallized in the mission. For Dugin, Russia's security depends on the expansion of Russian borders towards the West and the South, so the main modality of action - a new global anti-U.S. (anti-West by extension) alliance - needs to help in that expansion, too.

Dugin accused the Americans of building a New World Order (Dugin 2014: 48) - so it was his final analysis of the external environment. Yet, it is noteworthy reminding that it was Dugin himself who designed a plan for a New World Order. That New World Order should impose ways of life, promote oppressive control ending freedoms and destroying countries. A typical totalitarian plan, already seen in the past, is back.

Consequently, neo-Eurasianism does not constitute a geopolitical study that tries to explain political reality, but neo-Eurasianist proponents spread instead an ideology that, while using geopolitical concepts and methods, aims indeed to shape a New World Order through a clearly elaborated strategic
Assessing the role of Brazil in the New World Order: A geopolitical study of Meridionalism and neo-Eurasianism

Nuno Morgado 
plan, which naturally would grant to Russia a position of major power, if not world power, within a final oligarchic-global order. How Brazil is helping on this project is to be analyzed right away.

\section{Fundamental lines of Meridionalism as strategic plan}

It is believed that André Martin, professor of Political Geography at São Paulo University, is Brazil's most prominent author regarding the intellectual formulations on "geopolitics". Therefore, it is worthy to introduce Martin's Meridionalism and to analyze it in the English language for the first time (as it is perceived in the limits of the state of the art of my own research).

Martin asserted that his Meridionalism is a 'geo-ideology' - a term coined by Martin himself - whose central target is to grant, in the international chessboard, a special place to Brazil (Dugin 2014c). For that, naturally, the structure of international power must be changed, Martin contended. Hence, there is not much to add in terms of classification of Meridionalism as ideology, since the author himself already regarded it as such.

As for the understanding of how the power shift in the international arena should occur, it is required to analyze Martin's Meridionalism within the framework of strategic planning, as it was accomplished above for neoEurasianism.

Devoting himself to the study of geopolitics - understood by him in the limits of applied geopolitics exclusively (in the line of Couto e Silva) - Martin, in his $\mathrm{PhD}$ thesis, tried to define the basic concepts of the field: "space" and "power", clarifying that while space is different from territory, power is nothing but a capacity (Martin 1993). Martin also wrote an entire and interesting chapter about the concept of borders (Martin 1993: 75-94).

Concerning other concepts, however, it is considered that the definitions and distinctions among other concepts/fields of study are primitive. ${ }^{15}$ Martin mentioned the debate on the divisions among geopolitics and political geography (Martin 1993: 30), which has also remained too rudimentary in Brazil, taking into account that Martin insisted, in his 2007 habilitation thesis, that political geography and geostrategy are synonyms (Martin 2007: 8, 15). The literature in geopolitical studies advanced much about that topic even before 2007 (e.g. Chauprade and Thual 1998).

Meridionalism - Martin's major design - has become the center of his work, it might be argued. That 'geo-ideology' has been taking shape for the last twenty years (Martin 2007: I, Dugin 2014c).

15 In fact, it continues being so, i.e. the primitive knowledge has endured in Brazil. In an article in 2014, Albuquerque - one of the few Brazilian academics interested in geopolitics - used the terms "theory" and "ideology" to characterize Meridionalism, as if they had the same meaning (Albuquerque 2014). 
The ideology departs from the concept of Meridionalidade, a concept that is characterized, Martin explained, not only by economic and military fragility, but mainly by political and diplomatic limited relevance (Martin 1994: 113). In terms of position (Lage - geopolitical factor), the ideology focuses on the location in the "South" of the globe (Martin 1994: 114). In fact, that is a crucial condition at stake since the origin of the name (Meridional) can then be traced here.

The main point, that should be always kept in mind, is that Meridionalism is an ideology which - stressing the condition of Meridionalidade establishes the objective of pursuing "hemispheric cooperation" and exercising "international solidarity", based on the Westphalian principle of states equality (Martin 1994: 117). The rhetoric is characteristically a piece of Marxist structure with normative purposes that is unable to describe the reality objectively, since the "international solidarity" will necessarily destroy the Westphalian principle of national sovereignty (in this level, the case of São Paulo Forum is paradigmatic).

As ideology, Meridionalism is far from the richness of neo-Eurasianism, which has been trying to gather conservatives, Christians, Muslims, radical leftists, hardline communists, fascists, revolutionaries, etc. with a catch-all objective: the destruction of the "U.S. hegemony". As for Meridionalism, it is a plain leftist ideology based on the determinist Marxist call: "Meridionals from all the World, unite!". Therefore it seems that there is not much more to be analyzed in terms of roots of the ideology under examination, so the study can move forward to the analysis of the strategic plan.

\section{What does then Meridionalism exactly aim at?}

The Brazilian School of Geopolitics has formulated the direction already: Brazil should become a great power. Meridionalism aims now at becoming the ideology and the strategic plan that leads the movement towards such objective.

\section{Phase I. Analysis of the international environment by Meridionalism}

Starting from Brazil's geohistorical roots, Martin focused on the relevance of the influence by the Portuguese ${ }^{16}$. In fact, Martin contended that the roots of Meridionalism can be traced within the period of foundation of Portugal as independent state in the $12^{\text {th }}$ century.

In spite of Portugal being both a product of and a contributor to the West, Martin argued that Brazil is neither exclusively a country of the West-

${ }_{16}$ Therefore, it is possible to trace a direct link from Therezinha de Castro to Martin (Castro
Assessing the role of Brazil in the New World Order: A geopolitical study of Meridionalism and neo-Eurasianism

Nuno Morgado 1999). 
ern Civilization - Martin frequently quoted Huntington's "clash of civilizations" thesis and its division of civilizations -, nor a tropical country, but a meridional one. ${ }^{17}$

Martin's analysis of the environment also included the following statements: since the abandonment of Couto e Silva's plan, Brazil had no other strategic plan and Brazilian elites' perceptions and capacities are too "weak", compared to the state's potential, which Martin contended is strong enough to overcome the limits of a mere regional hegemony in South America or even in Latin America (Millennivm 2012).

Within this context, a fundamental idea in Martin's strategic plan is that, taking into account that once in history peoples from the "European periphery" (Portuguese and Spanish) started a new phase in the world history in terms of balance of power, now peoples from "world periphery" (the Southern Hemisphere) should follow the historical example of those mentioned peoples (from the "European periphery") and change the balance of powers themselves (Dugin 2014c).

At this point, it is then obvious that Brazil has a special role so that modifications in the structure of international system may take place. What Martin identified as the "zone of impotence" - the South Hemisphere ("warm, maritime, and scattered hemisphere") - is now the part of the world that must rise "against the North", Martin claimed (SimposioPolitica 2013).

Without any surprise, Martin adopted the rhetoric of neo-Eurasianism and argued that, currently, there are only two geo-ideologies on the globe: Atlantism "with values of individualism, commerce, democracy, human rights, USA as main proponent" and Eurasianism "that results from [the mixture of] bolshevism with pan-slavism", with values attached to agriculture, farms, large territorial borders, collectivism, communitarianism, non-individualism, and Russia as main proponent (Millennivm 2012, SimposioPolitica 2013).

Such perspective, attached to the Marxist structure of "struggle for liberation" induced then Martin to conclude: "the South is in danger, it is necessary to defend it, and Brazil can defend it" (Millennivm 2012). Moreover, Martin also supported the idea of a superiority of the "East" over the "West" something imprecise and that lacks convincing evidence. ${ }^{18}$

To Martin, without any surprise, the U.S.A. as a state is promoting plans for world domination (Martin 2007: 113, Dugin 2014c) - again an imprecise argument with short or none empirical verification. Consequently, Martin based his Meridionalism on anti-U.S. ground. In fact, in a critical review of Bandeira's book devoted to the U.S.A., Martin expressed visibly his anti-

${ }_{17}$ Martin relentlessly criticized what he called "the westernizer tendency in Brazilian people and elites", claiming that such propensity is not "fair" towards African and native American influences (Martin 1994: 115, Martin 2007: 113-114, Dugin 2014c).

18 Martin gave examples of "East" civilizing the "West" (e.g. Ancient Greece and Phoenicia), but other examples could be given in return (e.g. Constantinople was created after and as heir of Rome). 
U.S. perspectives (Martin 2006). Martin has been proposing an "anti-U.S. supremacy" in the world order, and he has been claiming that an "aero-naval conflict between Brazil and decadent Atlanticist powers" remains a possibility (Conferência Nacional 2013).

\section{Phase II. Formulation of strategic plan by Meridionalism}

In this way, the mission of Meridionalism was already mentioned and can be defined as: to change the balance of powers in the world. That corresponds to the same mission of neo-Eurasianism, just through other words: the destruction of the "unipolar world".

In order to accomplish that, Martin settled the objective that Brazil needs to become a major power on the international arena. So, as neo-Eurasianism established the objective of transforming Russia into a major - if not the most important - player on the international chessboard, so it did Meridionalism concerning Brazil. In a conference devoted to the topic "Brazil in the World Scenario", Martin claimed that "Brazil's role is crucial for World peace", and for that "Brazil needs to have a "great power plan» clearly defined". Going even beyond those already gigantic objectives, Martin affirmed: "only Brazil can save the World" (Martin 2007: 96, SimposioPolitica 2013).

Concerning the modalities of action, Martin suggested the development of military forces and the projection of military power as well as spreading an "ideological discourse beyond borders". The Meridionalist ideology is naturally Martin's proposal, taking into account that he added: "there is no projection of power without an international ideology" (e.g. Richelieu's Raison d'État) (Millennivm 2012).

As for Brazil's internal plan (relative material state potential), Martin proposed what he called the "anti-Golbery plan": the creation of a great navy (in the line of Mahan) and the construction of railways with continental dimensions (in the line of Mackinder and Travassos) (Martin 2007: 116, Millennivm 2012).

The true ally of Brazil should be India - these two states should cooperate and enter together in the Security Council, Martin formulated (Martin 2007: 112, Dugin 2014c). On the other hand, Brazil should also transform IBAS into "IBASA", i.e. bringing Australia into the group (Dugin 2014d).$^{19}$ Other directions of Brazilian foreign policy shall include Antarctica, Portugal and South Africa.

As for Russia and China, because they did never suffer colonialism, Martin stated, it is not believed that BRICS is a "geopolitical" project. In this context,

19 See also: Ministério das Relações Exteriores (2015). It is interesting to note the convergence with Cohen, who put both Brazil and Australia as "high" second-order powers (Cohen 2009: 49).
Assessing the role of Brazil in the New World Order: A geopolitical study of Meridionalism and neo-Eurasianism

Nuno Morgado 
Artículos y ensayos

Map 5.

Martin's geographical directions of his Meridionalist 'geo-ideology'

(Martin 2007: 112)

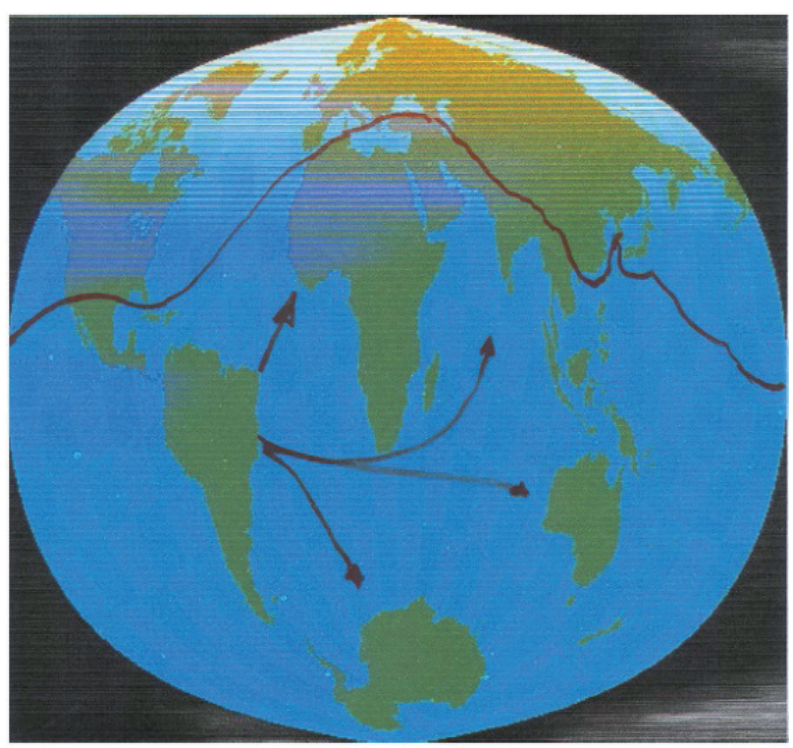

Martin characterized BRICS as a geoeconomic structure only (Martin 2007: 111, SimposioPolitica 2013).

Coming back to the objective, linking it with the modalities of action, there is a major inconsistency in Martin's project that needs to be highlighted. On the one hand, Martin made use of nationalist rhetoric praising a possible bright role for Brazil in the future, ${ }^{20}$ as it was above-mentioned. On the other hand, and absorbing the most misguided influences from the Brazilian School of Geopolitics, Martin has been insisting in the project of regional integration, which logically dissolves Brazil in the region (Martin 2007: 118).

As it was analyzed, in strategic terms, regional integration of Latin America has been an obstacle for Brazil's projection as a sea power. Martin claimed that Brazil needs to become a sea power, but at the same time he alluded to the "Great Bolivarian Fatherland" (Martin 2010: 37), which means the destruction of Brazil as independent state.

If it is true that Martin sustained that Meridionalism does not aim at the "integration of countries", but articulation of states (Martin 1994: 119), it is also true that Martin seemed cheerful about the velocity of the South American integration process until now, mentioning that the idea of a common currency and common military forces in South America is an idea on the order of the day for discussion. In this vein, Martin affirmed: "...all ideological forces are unanimous in the defense of that, so-called, common interest." (Martin 2010: 49)

\footnotetext{
${ }^{20}$ In the line of the Brazilian School of Geopolitics (also revealing interest in Antarctica).
} 
It seems that Martin disremembers that Brazil does not have balanced representation of different ideological standpoints at the Parliament, and certainly a right-wing force would not be willing to support measures of weakening national sovereignty. ${ }^{21}$

All the same, Martin touched the core of the problem while commenting that, since Lula da Silva took charge of Brazil's Presidential Office, Caracas and Brasilia joined positions (Martin 2010: 50) - and that is another direct empirical evidence of the effectiveness of São Paulo Forum's directives.

Hence, the logical inconsistency remains: either Brazil shall become an independent state projecting power on the sea as maritime country, or Brazil shall be dissolved in South and Latin America within the regional integration project. The analysis insists on this point.

Conflicting with the idea of regional integration, in the logics of opposition sea power $v s$. land power - an opposition accepted by Martin due to his use of neo-Eurasianist rhetoric - remains the project of Brazil as maritime power.

As quoted, this idea found several supporters in the Brazilian School of Geopolitics (e.g. Flores 1972) and Martin - although incoherently because of his support to regional integration - is another proponent of that goal.

Martin proclaimed Brazil's "Atlantic vocation" (Martin 1994: 115, Martin 2010: 45) ${ }^{22}$ apparently without realizing that another conflict of ideas is being created: if Brazil shall become a sea power, Brazil cannot, at the same time, join Eurasianist "land project", otherwise Meridionalism would become a "geo-ideology" of the seas, thus an Atlantist ideology.

So, while Martin explained in detail his rejection of the U.S. hegemony and the Atlantist project, claiming that Brazil can join forces with the Eurasianist project, simultaneously, Martin contended that "only naval powers can threat Brazilian security, since regional integration is decreasing territorial threats" (Millennivm 2012), thus Brazil must rise as sea power in name of its own defense. ${ }^{23}$

In terms of sectoral policies, Meridionalism did not provide much information. Martin just detailed, in his project, that using diplomatic and political instruments to apply the ideology of Meridionalism is essential, in order to spread the ideology not only regionally, but like all ideologies, to spread it on the globe and become universal (Martin 1994: 118).

By his writing style and his conclusions, there is no doubt that Martin tries to analyze international relations seriously. However, his Marxist mental structure, ("Marxist Geopolitics") (Martin 2007: 12) does not allow him to pursue a-ideological studies as a (scientific) geopolitical study must be. Martin's normative approach, his judgments of value do not let the reader free

\footnotetext{
${ }^{21}$ See positions of the member of Brazilian Federal Congress Jair Bolsonaro (e.g. JP Madeira 2014).

22 Furthermore, Martin's main study about geopolitics (Martin 2007) opens with a quotation about the importance of the sea.

${ }^{23}$ Meridionalism is, in fact, confusing on this issue, because it characterized Brazil as "hybrid" power (Martin 2007: 116).
}

Assessing the role of Brazil in the New World Order: A geopolitical study of Meridionalism and neo-Eurasianism

Nuno Morgado 
for an objective interpretation, because there is no intention to be objective whatsoever, since that possibility is denied by Martin (as it is denied by Dugin). The Marxist structure - and the expression includes neo-Marxist critical theory of international relations, etc. - is deeply committed with modifying the international system, instead of analyzing it in theoretical and abstract ways. Exactly the same problem was identified in neo-Eurasianism.

Martin insisted that ideology has a purpose of guiding foreign policy (Millennivm 2012), whereas it is exactly the opposite: when foreign policy ignores geopolitical studies' results in the name of ideology, state's failures happen. ${ }^{24}$

Other inconsistencies and flaws in Martin's Meridionalism were already identified: the priority falls upon regional integration or upon independent maritime power? Is Brazil perceived as a land power or a sea power? How can Brazil affirm an Atlantic vocation and become a sea power at the same time being an ally of the Eurasianist forces, fighting against Atlantism and against the main world sea power, the U.S.A.? Ideology versus science: Meridionalism as a geo-ideology uses the geographical setting (Dugin 2014c), but it is incompatible with the practice of science.

In conclusion, in an interview conducted by some of his students, Martin defined, with no space for doubts, that Meridionalism constitutes the "theory for emancipation of states from the South Hemisphere", and he confirmed also that Meridionalism may join forces with neo-Eurasianism (Matos 2013).

Therefore, the main argument of this article, stressing that there is a strong tendency of Meridionalism being used by neo-Eurasianism, now as well as in the future, if variables do not change, was duly supported.

\section{Conclusion}

The article assessed that both neo-Eurasianism and Meridionalism are put together into a joined "movement" with the purpose of gathering as much support as possible against the West and, most of all, against the U.S.A. The final mission of those two strategic plans is to destroy what they claim to be the "unipolar world" through a very biased analysis of the international chessboard. In other words, the article identified a common enemy both to neo-Eurasianism and Meridionalism that makes diverse (and antagonist) objectives, modalities of action and sectoral policies come together into a unified strategic movement of world dimensions. That dynamics of joining forces can be easily explained by the basic theoretical core that a strategy is always formulated against some "other" (Beaufre 1965).

Although both strategic plans suggested the creation of a multipolar world, a more thoughtful investigation uncovered the goal of creating an oligarchic-

24 Still, Martin himself recognized at the end that, in international politics, geography is more important than ideology (Martin 2007: 10). 
global order instead, especially in regard to neo-Eurasianism. Furthermore, the Russian intelligence community was acknowledged as the agent to operationalize the neo-Eurasianist project under Dugin's direct formulations.

In that oligarchic-global order, and with respect to South America, the national identity of Brazil would not be respected, since the purpose is to dissolve South (or even Latin) American countries' identities into a homogeneous region to be used as instrument in the global neo-Eurasianist strategy in pursuing its final mission.

In this context, both South American regional integration and the Meridionalist ideology and strategic plan have been giving a hand to neo-Eurasianism, and the article predicts it will continue so, if the variables remain the same.

With respect to Meridionalism, it seems that the task of formulating and operationalizing the strategic plan has been falling upon ideology. Thus, the internationalist leftist hegemony in Brazil has been reigning over the thinking about Brazil's strategy. Meridionalism is a branch of that leftist hegemony in the sense that it is partly internationalist and devoted to Latin American regional integration. Consequently, the influence of São Paulo Forum - which gathers all leftist movements and parties in South America with the goal of achieving a Latin American bloc - can be deduced in Brazilian politics (even against Brazil's national interests, as the contradictions within Meridionalism disclose).

Moreover, if that leftist ideological predominance is real, then Meridionalism, alike neo-Eurasianism, cannot be assessed as a geopolitical study about the essence of the reality, but simple as a product of an ideology committed to the Marxist aphorism of "changing the World".

In this context, it is that same ideological milieu, harmful from a scientific point of view, which creates inconsistencies in Meridionalism that the article identified and that can be systematized in two groups: an opposition between an independent Brazil versus Latin American regional integration and an opposition between Brazil as a sea power versus an alliance with Eurasianist land power bloc (within the land/sea clash that is accepted by Meridionalism).

Neo-Eurasianism is committed to a project for a New World Order. The empirical data collected and explained in this article allow sustaining that notion with convincing evidence. Besides, also Meridionalism is dedicated to a similar project for a New World Order. In this context, the conclusion can be resumed in one sentence: both projects have connections in both academic and strategic terms.

\section{References}

ABI (2009), Entrevista - Ancelmo Gois, "Associação Brasileira de Imprensa”, August 2009, http://www.abi.org.br/entrevista-ancelmo-gois-2/, access: 14.10.2016.

Abranches M., Petrilák V. (2016), Arquivos do Serviço Secreto do Bloco Soviético no Brasil, “Cepol24”, May 2016, http://www.cepol24.pl/stb_bra.html, access: 14.10.2016.
Assessing the role of Brazil in the New World Order: A geopolitical study of Meridionalism and neo-Eurasianism

Nuno Morgado 
Albuquerque E. S. (2014), A teoria geopolítica meridionalista de André Martin, "Revista de Geopolítica”, vol. 5, no 2, pp. 5-18.

Beaufre A. (1965), An Introduction to Strategy: With Particular Reference to Problems of Defense, Politics, Economics and Diplomacy in the Nuclear Age, Praeger, New York.

Bittman L. (1985), The KGB and Soviet Disinformation - An Insider's View, Pergamon, Washington D.C.

Castro T. (1999), Geopolítica - Princípios, Meios e Fins, Biblioteca do Exército, Rio de Janeiro.

Chauprade A., Thual F. (1998), Dictionaire de Géopolitique - États, Concepts, Auteurs, Ellipses, Paris.

Cohen S. B. (2009), Geopolitics - The Geography of International Relations, Rowan \& Littlefield Publishers, Lanham.

Conferência Nacional 2003 -2013: Uma Nova Política Externa, 17.07 Mesa 1: Política Externa Brasileira e Defesa, "YouTube", August 2013, https://www.youtube.com/ watch?v=H8I5xE2FVw8, access: 14.10.2016.

Douguine A. (2006), Le prophète de l'eurasisme, Avatar, Paris.

Дугин А. (2000), Основы Геополитики - Геополитическое будущее России, Арктогея, Москва.

Dugin A. (2008), The Great War of Continents, “The Fourth Political Theory”, http://4pt.su/ en/content/great-war-continents, access: 14.10.2016

Dugin A., The United States and the New World Order, "Giuliano Morais \& Ricardo Almeida’s Blog”, January 2011, http://debateolavodugin.blogspot.cz/ access: 14.10.2016

Dugin A. (2014a), Putin vs Putin - Vladimir Putin Viewed from the Right, Arktos, United Kingdom.

Dugin A. (2014b), Eurasian Mission - an Introduction to Neo-Eurasianism, Arktos, United Kingdom.

Dugin A., Meridionalismo: geoideologia. Prof. Andre Martín, "YouTube", September 2014c, https://www.youtube.com/watch?v=tfEs9M1KPCw, access: 14.10.2016.

Dugin A., São Paulo A. Dugin/A. Martin, "YouTube", September 2014d, https://www. youtube.com/watch?v=78IHwoyxdO8, access: 14.10.2016.

Dugin A., The Metaphysics of National Bolshevism, "Arctogaia”, April 2016a, http://arctogaia. com/public/eng-teor.htm access: 14.10.2016.

Dugin, A., The Long Path: An Interview with Alexander Dugin, “Open Revolt”, May 2016b, https://openrevolt.info/2014/05/17/alexander-dugin-interview/, access: 14.10.2016.

Fdfrankify, Larry Bittman BBC Interview 1990, "Youtube", December 2012, https://www. youtube.com/watch?v=sszmFjMGfws, access: 14.10.2016.

Flores M. C. (ed.) (1972), Panorama do Poder Maritimo Brasileiro, Serviço de Documentação Geral da Marinha, Rio de Janeiro.

Freeman M., A KGB revela como espionou o Brasil, "Youtube", April 2014, https://www. youtube.com/watch? $\mathrm{v}=\mathrm{m}$-YSbbiiCTk, access: 14.10.2016.

Gheller G. F., Gonzales S. L. M., Mello L. P. (eds.) (2015), Amazônia e Atlântico Sul: desafios e perspectivas para a defesa no Brasil, Instituto de Pesquisa Econômica Aplicada, Brasília. 
Laos N. (2015), The Metaphysics of World Order - a Synthesis of Philosophy, Theology, and Politics, Pickwick Publications, Eugene.

Magalhães L., O Brasil nos Arquivos Soviéticos de Espionagem (áudio melhorado), "Youtube", June 2014a, https://www.youtube.com/watch?v=GLIb0H_3ljU, access: 14.10.2016.

Magalhães L., O Brasil nos arquivos da STB "Dalibor, a louça e a amizade", "Youtube", October 2014b, https://www.youtube.com/watch?v=r9LpFNq3llc, access: 14.10.2016.

Lulko L., Rússia criaria o sistema da defesa aeroespacial do Brasil, "Pravda", February 2013, http://port.pravda.ru/russa/05-02-2013/34261-sistemaaero-0/, access: 14.10.2016.

Martin A. R. (1993), As fronteiras internas e a "questão regional" do Brasil, Ph.D. thesis, Universidade de São Paulo.

Martin A. R. (1994), Qual é o nosso «Bloco»? O Brasil procura o seu lugar no mundo, in: O Novo Mapa do Mundo - Globalização e Espaço Latino-Americano, F. C. Scarlato, M. Santos, M. A.A. de Souza, M. Arroyo (coords.), São Paulo.

Martin A. R. (2006), Contra-ataque ao Império, "Revista Brasileira de Ciências Sociais", vol. 21, no 62, http://www.scielo.br/scielo.php?script=sci_arttext\&pid=S010269092006000300012\&lng=pt\&nrm=iso, access: 14.10.2016.

Martin A. R. (2007), Brasil, Geopolítica e Poder Mundial - o anti-Golbery, Livre-Docência thesis, Universidade de São Paulo.

Martin A. R. (2010), Sopa de Letrinhas: ALBA, ALCA, MERCOSUL, UNASUL, CAN... para onde vai a integração latinoamericana?, in: Argentina e Brasil: Possibilidades e obstáculos no processo de integração territorial, M. Arroyo, P. Zusman (eds.), Humanitas, São Paulo.

Matos D., Programa Conectado com Dídimo Matos entrevista André Roberto Martin, "YouTube", April 2013, https://www.youtube.com/watch?v=1hQr21W56M4, access: 14.10.2016.

Meira Mattos C. (2011), Geopolítica e Modernidade, in Geopolítica Vol. III, ed. Biblioteca do Exército, FGV Editora, Rio de Janeiro.

Millennivm, O Meridionalismo Geopolítico - Palestra do André Martin no Congresso Nacional Brasileiro, "YouTube", December 2012, https://www.youtube.com/watch?v=oABdxQGLG0, access: 14.10.2016.

Ministério das Relações Exteriores, Mecanismos Inter-Regionais IBAS - Fórum de Diálogo Índia, Brasil e África do Sul, "Itamaraty", June, 2015, http://www.itamaraty.gov.br/index. php?option $=$ com_content $\&$ view $=$ article $\&$ id $=3673$ :forum-de-dialogo-india-brasil-eafrica-do-sul-ibas\&catid=170: chamada-1\&Itemid=436\&lang=pt-BR, access: 14.10.2016.

Miyamoto S. (1987), Geopolítica e Política Externa Brasileira, UNESP, Marília.

Morgado N. (2015), Desvelando o planeamento estratégico de Otto von Bismarck A fundação do II Reich e a Unificação Alemã de uma perspectiva da Estratégia, "Finis Mundi Journal of metapolitics, history \& culture", no 9, pp. 40-69.

Morgado N. (2016), Continentalization versus Maritimization - the debate within Brazilian School of Geopolitics and its political consequences, in: 3rd International Multidisciplinary Scientific Conference on Social Sciences \& Arts, SGEM Vienna Hofburg, Book 2 Political Sciences, Law, Finance, Economics \& Tourism, Volume I Political Science, SGEM International Multidisciplinary Scientific Conference on Social Sciences \& Arts, Sofia.

Pacepa I. M., Ex-espião da União Soviética: Nós criamos a Teologia da Libertação, "Acidigital", May 2015, http://www.acidigital.com/noticias/ex-espiao-da-uniao-sovietica-nos-criamosa-teologia-da-libertacao-28919/, access: 14.10.2016.
Assessing the role of Brazil in the New World Order: A geopolitical study of Meridionalism and neo-Eurasianism

Nuno Morgado 
Romancov M. (2006), Quo vadis, Russia? Current Russian position between Asia and Europe, in Contemporary security dilemmas: reflections on security in East Asia and Central Europe, L. Cabada, Š. Waisová, Aleš Čeněk (eds.), Plzeň.

Scalea D., Panarin e la disintegrazione degli USA, "Eurasia”, April 2009, http://www.eurasiarivista.org/cogit_content/articoli/EkFlZyylZypqtmvasE.shtml, access: 14.10.2016.

SimposioPolitica, André Roberto Martín (USP), $3^{\circ}$ Simpósio Nacional de Geografia Política, "YouTube", December, 2013, http://www.youtube.com/watch?v=Dm8cVCtbObQ, access: 14.10.2016.

Wohlforth W. C. (1999), The Stability of a Unipolar World, "International Security", vol. 24, no 1, pp. 5-41. 